\title{
CAPACITY DEVELOPMENT FOR SMALLHOLDER IRRIGATION IN KENYA ${ }^{\dagger}$
}

\author{
BANCY M. MATI* \\ International Crops Research Institute for Semi-Arid Tropics (ICRISAT), Nairobi, Kenya
}

\begin{abstract}
This paper presents the experiences on capacity development for irrigation in Kenya, drawing from a study of seven smallholder irrigation schemes, namely: New Mutaro, Emening, Mitunguu, Ng'uuru Gakirwe, Lari, MukuriaKyambogo and Isiolo River Water Users Association. These schemes were selected for their apparent success in irrigation management, sustainability and poverty reduction among the beneficiaries. Although the seven schemes had diverse innovations and enterprises, common drivers of success were identified as: (i) introduction of new knowledge/technology, (ii) availability of markets, (iii) good governance structures, (iv) funding for infrastructure development, and (v) targeted capacity development. It was also found that initial investment costs for smallholder irrigation schemes ranged from about US \$198 to \$1744 per ha, which is much lower than reported for large public schemes. Generally, all the schemes had recorded improved food security and incomes, with net earnings ranging from US \$200 to \$1200 per month for single-crop enterprises. Capacity development had played a major role in the positive performance of the schemes. However, the respective schemes had experienced different modes of capacity building, which included government extension services, NGOs, private sector, research institutes, out-grower support schemes and farmer-to-farmer learning. This paper focuses on the role of capacity development. Copyright (C) 2008 John Wiley \& Sons, Ltd.
\end{abstract}

KEY WORDS: smallholder irrigation; capacity development; poverty reduction; Kenya

Received 27 February 2008; Revised 5 April 2008; Accepted 6 April 2008

\section{RÉSUMÉ}

Cet article présente les expériences sur le développement des capacités pour l'irrigation au Kenya, tirées d'une étude de sept projets d'irrigation pour petits exploitants à savoir; Nouveau Mutaro, Emening, Mitunguu, Ng'uuru Gakirwe, Lari, Mukuria-Kyambogo et l'Association d'Utilisateurs Isiolo River Water. Ces projets ont été choisis pour leur succès apparent dans la gestion de l'irrigation, la durabilité et la réduction de pauvreté parmi les bénéficiaires. Bien que les sept projets aient des innovations et réalisations diverses, les raisons communes de succès ont été identifiés comme: (i) l'introduction de nouvelles connaissances/technologies, (ii) la disponibilité des marchés, (iii) les bonnes structures de gouvernance, (iv) le financement pour le développement des infrastructures et (v) le développement des capacités finalisé. Il a aussi été constaté que les prix initiaux d'investissement pour les projets d'irrigation pour petits exploitants ont varié d'environ 198 US\$ à 1744 US\$ par ha, ce qui est beaucoup plus faible que les coûts annoncés pour les grands projets publics. Généralement tous les projets ont enregistré une amélioration de la sécurité alimentaire et des revenus, avec des revenus nets variant 200 US\$ à 1200 US\$ par mois en simple récolte. Le développement des capacités a joué un rôle important dans les bonnes performances des projets. Pourtant, les projets ont connu différents modes de renforcement des capacités incluant les services de vulgarisation gouvernementaux, les ONG, le secteur privé, les instituts de recherche, la culture sous contrat, et

\footnotetext{
* Correspondence to: Bancy M. Mati, International Crops Research Institute for Semi-Arid Tropics (ICRISAT), PO Box 39063 Nairobi, Nairobi 00623, Kenya. E-mail: b.mati@cgiar.org

${ }^{\dagger}$ Le développement des capacités d'irrigation des petits exploitants au Kenya.
} 
l'apprentissage de fermier à fermier. Cet article se concentre sur le rôle du développement des capacités. Copyright (C) 2008 John Wiley \& Sons, Ltd.

MOTS CLÉs: irrigation pour petits exploitants; développement de capacité; sécurité alimentaire; réduction de pauvreté; Kenya

\section{INTRODUCTION}

Capacity development for irrigated agriculture in Kenya has always suffered from lack of targeted extension services, as training is normally provided by staff from the Ministry of Agriculture, who are general practitioners. Up until 2003, the Irrigation and Drainage Branch was hosted by the Ministry of Agriculture, and therefore extension services were easily streamlined within the Ministry. During the ministerial reforms of 2003, the Irrigation and Drainage Branch was shifted to the Ministry of Water, and upgraded to a full Department (Irrigation and Drainage Department, 2003). Whereas this streamlined the water services provision, capacity building, especially for agronomy and other biological aspects of irrigated agriculture, has continued to be offered by the Ministry of Agriculture. This apparent administrative disconnect has affected operations as lines of command became mixed up. Moreover, most of the extension staff from the Ministry of Agriculture have been trained on rain-fed agriculture, while the specialized systems of production under irrigated cropping, which sometimes involves growing of exotic marketable produce, leaves a knowledge gap which farmers have to address themselves. It is therefore necessary to identify better mechanisms that enable new knowledge to reach farmers engaged in irrigation. This is particularly urgent since irrigation is a very important sector of Kenya's economy, responsible for increased crop and livestock productivity, and especially since almost all commercial horticulture in Kenya is irrigated. Furthermore, fresh horticultural exports earn Kenya US \$555 million (Republic of Kenya, 2006), which is the highest agricultural foreign exchange earner in the country.

Current estimates indicate that Kenya has a potential for irrigation of 540000 ha (Republic of Kenya, 2003). About 106600 ha have been put under irrigation, comprising $20 \%$ of the potentially irrigable area. Large commercial farms cultivate $40 \%$ of irrigated land; government-managed schemes cover $18 \%$, while smallholder individual and group schemes take up $42 \%$ of irrigated land (Republic of Kenya, 2004). Smallholder irrigated agriculture produces the bulk of local horticultural produce consumed in Kenya, as well as some export crops, and a substantial amount of dairy products. In the medium and high rainfall areas, supplementary irrigation based on surface flows has been instrumental in increasing productivity of high-value crops (Herdijk et al., 1990; Mati, 2002). The major constraints facing smallholder irrigation in Kenya include shortage of water as well as market availability, instability and unpredictability, both locally and abroad. In addition, farmers are frustrated by middlemen who swindle them or offer very poor prices, even when consumer prices are good (Mati and Penning de Vries, 2005). With over $80 \%$ of the smallholder irrigation schemes in Kenya being furrow-based, irrigation efficiency is very low, while facilities for post-harvest processing and handling are poorly developed. There is lack of a national irrigation policy, while inadequate investments have led to poor development of irrigation infrastructure and water storage facilities (Irrigation and Drainage Department, 2006). There is also inadequate technical capacity affecting farmers' organization and participation.

\section{CAPACITY BUILDING OF FARMERS IN KENYA}

Capacity building initiatives for farmers in Kenya are in the portfolio of the Ministry of Agriculture, including irrigated agriculture. There have been some notable extension programmes over the years. For instance, the Training and Visits (T\&V) of the 1980s was an extension project funded by the World Bank and implemented in 41 districts. It was meant to replace the tradition extension system inherited from the colonial government, which had failed to improve production in smallholder farming, as it was fraught with too much bureaucracy (Gautam, 2000; Pickering, 1989). Under T\&V, the concept of the model farmer was promoted, in which progressive farmers were identified where experiments and demonstration plots would be set up on their farms. However, adoption rates were disappointing, as the visiting farmers, for one reason or other, could not identify with the model farmer. 
A more recent extension package has been the National Agricultural and Livestock Extension Programme (NALEP) (Ministry of Agriculture and Rural Development, 2000). The programme has bottom-up stakeholder participation in decision-making, planning and implementation of activities, as well as a structured supervision, reporting, monitoring and evaluation (Baiya, 2000). However, NALEP has been bogged down by too much data collection with little follow-up activities.

Another programme, the Farmer Field School (FFS), described as a "school without walls", is a participatory method for technology development and dissemination (Okoth et al., 2002; Duveskog, 2001). The school involves 25-30 farmers in a given locality where the focus is field observations, hands-on activities and season-long research. However, FFS has only been applied in a few districts. The Agricultural Technology and Information Response Initiative (ATIRI) has been a participatory research programme implemented by the Kenya Agricultural Research Institute (KARI), meant to improve farmers' ability to make demands on agricultural service providers and intermediary organizations (Kenya Agricultural Research Institute, 2001). In the ATIRI approach, proposals are formulated by farmers' groups and all activities are focused on the identification, adaptation and promotion of new technologies as well as preservation and dissemination of indigenous technologies. In general, many of these extension packages have ended with as many problems as successes, with most of them having a strong focus on rain-fed agriculture. Smallholder irrigated agriculture has not had capacity building initiatives at national level specially targeted at them. In recent years, NGOs, private sector and research organizations have also been supporting capacity development, and their role in smallholder irrigation has been especially pertinent.

Recent water reforms have been implemented which seek to enhance community participation in irrigation development and management, as well as build capacity for both staff and farmers. The strategies to improve irrigation water management at farm level are also clearly spelt out, particularly how to involve communities in water resource management, distribution and equitable sharing (Ministry of Water Resources Management and Development, 2003). The current government strategy for capacity building in the agricultural sector (Republic of Kenya, 2004) highlights the need to reform extension services in the country. However, the proposed reforms target the Ministry of Agriculture, which no longer holds the portfolio for irrigation. Thus, irrigated agriculture still faces the challenge of having to outsource extension services from another Ministry or from other sources. To this end, capacity development for smallholder irrigated agriculture has been evolving, as was found in this study.

\section{DATA ACQUISITION AND METHODS}

This study sought to determine how capacity development in smallholder irrigation schemes in Kenya is achieved and the consequent impacts on poverty reduction. Prior identification of candidate smallholder schemes was done through meetings with staff from the Irrigation and Drainage Department (IDD), NGOs and other professionals engaged in the irrigation subsector, including review of records kept by the IDD. About ten smallholder irrigation schemes were first identified and visited as part of a wider study to identify irrigation successes in Kenya. Of these, seven irrigation schemes were considered suitable for further detailed study. These were:

- Emening Smallholder Farmers Group, Koibatek District;

- Lari-Wendani Smallholder Irrigation Scheme in Nakuru District;

- Mukuria-Kyambogo Irrigation Scheme, Meru Central District;

- New Mutaro Irrigation Scheme, Laikipia District;

- Isiolo River Water Users Association (IRWUA), Isiolo District;

- Mitunguu Irrigation Scheme, Meru Central District;

- Ng'uuru-Gakirwe Water Project, in Tharaka District.

Each irrigation scheme was further assessed through field visits and meetings with district staff, extension officers, scheme managers, government officials in the target areas, as well as focused group discussions with local leaders. The farms were visited and assessed through semi-structured questionnaires administered to the male and/ or female farmers present at the sampled farm. Observations of the status of irrigation, crop enterprise and 
infrastructure were also made. The study interviewed, in total, about 25 officials and 50 farmers. The information gathered included background to the scheme, origins of the innovation, crops grown, marketing, infrastructure, extension services and sources of new knowledge, modes of learning, and management of group resources, e.g. water, credit, membership as well as costs and benefits. The data obtained from the field surveys were mostly qualitative, while quantitative data, such as costs and prices of produce, depended largely on farmer recall since farm records (considered confidential by the farmers) were not made available to the researcher.

\section{PROFILES OF THE SMALLHOLDER IRRIGATION SCHEMES SAMPLED}

In much of rural Kenya, smallholder farmers wait for "development to be brought by the government". These types of sentiments are particularly strong in the dry areas, which have in the past attracted many NGOs, giving local communities enhanced expectations for external assistance (Mati, 2005). Similar sentiments had existed among the communities in the seven schemes. Thus, irrigation is viewed as one of those interventions which must be brought by the government or NGOs. Each of the seven irrigation schemes in this study had unique innovations, which contributed to the profitability of the major enterprises, improving the livelihoods of farmers as well as sustainable management of the scheme. There are variations too in the way each innovation developed, investment costs, the crops grown and the average earnings by the farmers (Table I). Capacity development to a large extent affected the types and quality of enterprises adopted by farmers. These are described for each scheme as follows:

Table I. Characteristics of the smallholder irrigation schemes assessed

\begin{tabular}{|c|c|c|c|c|c|c|c|}
\hline Scheme name & $\begin{array}{c}\text { No. of } \\
\text { households }\end{array}$ & $\begin{array}{l}\text { Area } \\
\text { (ha) }\end{array}$ & $\begin{array}{l}\text { Initial } \\
\text { investment } \\
\text { (US \$) }\end{array}$ & $\begin{array}{c}\text { Investment } \\
\text { per ha } \\
\left(\mathrm{US} \$ \mathrm{ha}^{-1}\right)\end{array}$ & $\begin{array}{l}\text { Income } \\
\text { from main } \\
\text { crops US \$ } \\
\text { per month }\end{array}$ & $\begin{array}{l}\text { Innovation and main } \\
\text { enterprise }\end{array}$ & $\begin{array}{l}\text { Capacity development } \\
\text { support }\end{array}$ \\
\hline Emening & 47 & 12 & & $\begin{array}{c}1100 \\
\text { (individual) }\end{array}$ & $200-500$ & $\begin{array}{l}\text { Group scheme based } \\
\text { on individual initiative } \\
\text { and production of } \\
\text { watermelon }\end{array}$ & $\begin{array}{l}\text { Ministry of Agriculture } \\
\text { and Ministry of } \\
\text { Water and Irrigation }\end{array}$ \\
\hline $\begin{array}{l}\text { Lari- } \\
\text { Wendani }\end{array}$ & 94 & 80 & No data & & $250-600$ & $\begin{array}{l}\text { Community management, } \\
\text { water sharing and local } \\
\text { vegetables }\end{array}$ & $\begin{array}{l}\text { Ministry of Agriculture } \\
\text { and Ministry of Water } \\
\text { and Irrigation }\end{array}$ \\
\hline $\begin{array}{l}\text { Mukuria- } \\
\text { Kyambogo }\end{array}$ & 15 & 56 & 11000 & 198 & $500-1200$ & $\begin{array}{l}\text { EUREP-GAP certified } \\
\text { for export vegetables } \\
\text { and partnerships with } \\
\text { commercial companies }\end{array}$ & $\begin{array}{l}\text { Commercial horticultural } \\
\text { exporters }\end{array}$ \\
\hline $\begin{array}{l}\text { New } \\
\text { Mutaro }\end{array}$ & 2000 & 120 & 34286 & 286 & $300-500$ & $\begin{array}{l}\text { Extensive irrigation of } \\
\text { fodders for dairying }\end{array}$ & $\begin{array}{l}\text { Cooperative society } \\
\text { Commercial } \\
\text { horticultural exporters }\end{array}$ \\
\hline $\begin{array}{l}\text { Isiolo } \\
\text { RWUA }\end{array}$ & 5,000 & & No data & & $200-500$ & $\begin{array}{l}\text { Hydrological restoration } \\
\text { of water resources, } \\
\text { WUA management and } \\
\text { water sharing } \\
\text { (local vegetables) }\end{array}$ & NGOs \\
\hline Mitunguu & 600 & 400 & 530000 & 1325 & $500-1125$ & $\begin{array}{l}\text { Marketing and extensive } \\
\text { banana production }\end{array}$ & $\begin{array}{l}\text { Ministry of Agriculture } \\
\text { Researchers }\end{array}$ \\
\hline $\begin{array}{l}\text { Ng'uuru- } \\
\text { Gakirwe }\end{array}$ & 430 & 430 & 750000 & 1744 & $250-375$ & $\begin{array}{l}\text { Production, processing } \\
\text { and export of exotic } \\
\text { herbs by farmers }\end{array}$ & $\begin{array}{l}\text { NGOs Commercial } \\
\text { exporters }\end{array}$ \\
\hline
\end{tabular}

${ }^{\mathrm{a}}$ Incomes are based on actual areas cultivated (usually about 0.1 ha) per crop enterprise, and are not adjusted into incomes per ha. 


\section{Emening Smallholder Farmers Group}

This was started when one individual farmer bought a motorized pump in 1988 and started growing vegetables with water from Emening River. Soon, a few more farmers also bought pumps and the number of irrigators grew quickly. By 2004, there were 47 farmers actively engaged in irrigation. The farmers then formed and registered a self-help group, which has a well-organized management structure, to ensure coordinated water sharing, and provision of credit to new and upcoming farmers. They grow local horticultural crops, with special emphasis on watermelons, as the crop is not eaten by goats (an important livestock resource). Capacity building was provided by government extension system, and has been instrumental in assisting farmers formalize their governance structures and introduction of other crops to complement watermelons.

\section{Lari-Wendani Irrigation Scheme}

This was started in 1986 as a group scheme, through technical assistance by the Ministry of Agriculture, which developed the physical infrastructure. The original farmers numbered 94 and, although the population has grown, irrigation scheduling in blocks has remained unchanged. It covers 80 ha and water is drawn from a small perennial stream. The farmers grow mainly fresh vegetables such as tomatoes, onions and kale during the dry season for sale in towns. The main innovation was management of the scarce water by the farmers themselves, through their water users association. The farmers have designed their own water-sharing plans, which are strictly timed and adhered to, ensuring equitable water distribution. Food security and poverty reduction were reported to be the greatest achievements at Lari-Wendani. Capacity development is through the combined efforts of the Ministry of Agriculture and the Ministry of Water and Irrigation. This was particularly necessary at the beginning, since the farmers had no prior experience with irrigation and horticulture.

\section{Mukuria-Kyambogo Irrigation Scheme}

This is an example of how partnerships between large commercial farms and smallholder out-growers can succeed in enabling smallholder irrigators to fulfil the EUREP-GAP protocols and access European Union fresh-produce markets. The scheme was started in 1994 by a group of 15 farmers. There was cost sharing as farmers built the water intake using their own contributions and labour, while a loan of US $\$ 11000$, obtained through an NGO (SISDO), was used to buy materials such as pipes, sprinklers and gate valves, for the piped, gravity-fed sprinkler scheme. Each farmer paid back the loan at US \$16 per month, and within 48 months the loan was paid up. The group started by growing local vegetables like carrots, cabbage and potatoes, but there were problems with marketing. In 2000, farmers switched to growing fresh produce for export such as snow peas, sugar snaps and garden peas, supported by elaborate partnerships with large commercial exporters, such as Homegrown. The partnerships are made legally binding through signed agreements, while support capacity development services were provided by the commercial firm. Farmers estimated earnings to average about US \$1200 per month from a crop of sugar snaps. The capacity-building support and supervision given by the large commercial exporters was instrumental in helping the smallholder farmers learn to grow exotic crops and to acquire EUREP-GAP certification.

\section{New Mutaro Irrigation Scheme}

The New Mutaro Irrigation scheme is unique, being one of the few schemes, which have dedicated land for irrigated fodder, which is rare in Kenya. This is because in Kenya most irrigation schemes have by-laws which forbade the irrigation of fodder. Thus, livestock keeping tends to be a lesser by-product rather than a major enterprise. The New Mutaro was constructed in 1983 as a canal-based, gravity-fed scheme with funding from the Kenya Government and European Economic Community. The original members numbered 180 but by 2004 the numbers had grown to about 2000 . The scheme covers 120 ha but each farmer is allowed to irrigate 0.8 ha only, due to water shortage. Other than fodder, grown by over 100 farmers, farmers also grow local and export vegetables. Dairying was considered by farmers to be a more reliable enterprise compared with vegetables, whose market 
instability frustrated them. Capacity development had been enhanced through a cooperative society that the farmers ran, and which was especially instrumental in supporting the dairy activities. The cultivation, packaging and marketing of export vegetables were supported by partnerships with commercial exporters, while dairying was managed through the farmers' cooperative.

\section{Isiolo River Water Users Association (IRWUA)}

IRWUA is situated in arid northern Kenya, prone to drought, land degradation and water conflicts. IRWUA started as a Water Caretaker Committee of the Isiolo River Catchment in the early 1990s. Their first project in 1996 was to rehabilitate the degraded Rugusu spring and its riparian lands, which drain into Isiolo River. The success of the spring protection improved water flows from the Rugusu River, which subsequently became perennial within three years, with this water benefiting over 50000 people through water for drinking, livestock and irrigation. In addition, the flows of the river Isiolo stabilized, providing water throughout the year, and therefore reducing conflicts with downstream users, mostly pastoralists and irrigators. IRWUA's mandate covers the entire Isiolo River Catchment, divided into five geographic zones and bringing together 40 self-help groups under the same management. The Association oversees water sharing by irrigators, pastoralists, the Isiolo town and other users, and has helped put down water-related conflicts in the catchment. Capacity development was provided by NGOs, which also facilitated resource mobilization for the spring protection project.

\section{Mitunguu Irrigation Scheme}

This was initiated in 1985 through a grant from the Government of Kenya and GTZ. The funds were used for surveys, construction of new intake, pipe layouts and construction of cooperative society buildings. The original design was 400 ha for 309 farmers, but by 2004 there were over 600 irrigating farmers. The scheme operates as a gravity-fed piped sprinkler system and has seen many changes in crops grown, starting with local vegetables, dairy, Asian and export vegetables, but due to frustrations with marketing and middlemen farmers shifted to growing irrigated bananas. This has reduced the influence of middlemen, giving farmers some leverage and bargaining space (time-wise) resulting in relative price stability and a marketing system controlled by the farmers themselves. The banana crop usually earned farmers between US $\$ 500$ and $\$ 1125$ per month. Capacity development had been instrumental in the introduction of high-yielding banana varieties and agronomy. This had involved farmer trials with researchers from the Kenya Agricultural Research Institute, NGOs and government extension staff. The interaction with researchers had a great impact as farmers in the scheme were always experimenting with different methods of water application, different varieties and general field management.

\section{Ng'uuru Gakirwe Water Project}

This was started in 1985 with a group of 15 smallholder farmers, who initiated plans to abstract water from the nearby River Kithinu for domestic use, but later used it for irrigation. By 1987, the farmers, now numbering 107, approached the Catholic Diocese of Meru for technical and financial assistance to implement the project for irrigation. The project was implemented in three phases through grants from donors and the government to the tune of US $\$ 750$ 000. It serves 430 farming households with piped sprinkler irrigation, creating direct employment for over 3000 people. Each farmer is allowed to irrigate a maximum of 0.4 ha. The most interesting aspect of this scheme is that it produces high-value organic herbs (chamomile, carcade and lemon grass), which are processed and packaged at the factory run by farmers, and the produce is exported to niche markets in Europe and Japan. Food crops are also irrigated for home consumption. Capacity development of the scheme benefited from government extension staff, who handled water management, while NGOs and the private sector taught farmers how to grow and process the herbs, which was a completely new enterprise to them. Farmers are continually learning, and the demand to be certified as organic farmers was more than the factory could handle. 


\section{GENERAL OBSERVATIONS ON CAPACITY DEVELOPMENT IN IRRIGATED AGRICULTURE}

This study found that in these seven smallholder irrigation schemes most of the farmers had little prior experience with irrigated agriculture before the scheme started, since nearly all the farmers had previously been engaged in rain-fed agriculture. Moreover, irrigation is not a traditional practice among all the communities in the seven study areas, since traditional agriculture used to be rain-fed shifting cultivation, and in the case of Emening the farmers had previously been pastoralists. In all the schemes, irrigation was brought on board accompanied by some level of capacity development, especially training on water management, crop husbandry and handling of new and exotic crops, pest and disease management, marketing, and also how to operate collectively in groups. Generally, extension services to both rain-fed and irrigated agriculture in Kenya are provided by the Ministry of Agriculture (Republic of Kenya, 2004). However, the extension staff usually come from a background in rain-fed agriculture and are trained to deal particularly with issues of rain-fed farming (National Agricultural and Livestock Extension Program, 2004). Moreover, few extension workers have specialized training in the management of water for the intricate production systems of unique export crops. The separation of irrigation from the Ministry of Agriculture to the Ministry of Water and Irrigation means that extension services in irrigation schemes are offered by staff that are not answerable to the Ministry under which the scheme falls, and this can create administrative constraints. In this study, capacity development was distinguished across four systems: (i) government extension staff, (ii) NGOs, (iii) private sector, and (v) farmer-to-farmer exchange visits and learning. These are described as follows.

\section{Capacity development through government extension staff}

Extension services provided by the Ministry of Agriculture staff was the mode of learning at Lari-Wendani, Emening and Mitunguu irrigation schemes. The Ministry of Agriculture also deploys the managers for the schemes, while overall oversight is vested in the Ministry of Water and Irrigation, through its Irrigation and Drainage Department. Farmers are trained through field days and meetings, in which farmers would come together and learn at the farm of one of their members. Current thinking in Kenya (National Agricultural and Livestock Extension Program, 2004) is that extension through government services will be reformed to become private sector led and demand driven. But for irrigated agriculture, owing to its commercial and relatively specialized nature, this has already been happening. Some farmers as at New Mutaro have been making use of private companies, especially horticultural exporters, to learn how to grow exotic vegetables and use new equipment, but the services are paid for "in kind" through contractual agreements to sell produce to the service provider. There is scope for irrigated agriculture to embrace the new changes in extension privatisation much more effectively than under rain-fed systems, since the agricultural enterprises are more market oriented.

\section{Capacity provided through NGOs}

Non-governmental organizations (NGOs) have been instrumental in facilitating the start-up and implementation of some of the smallholder irrigation schemes, such IRWUA and Ng'uuru Gakirwe. Training by NGOs closely resembles that by government extension workers and may involve field days. However, as NGOs have better resources and are focused on specific schemes, they tend to engage in more activities than government extension. They take farmers on tours to other parts of the country, thereby broadening perceptions and knowledge of the group. NGOs also organize training workshops facilitated by subject matter specialists, and may even provide some input. It was such training that enabled the farmers of Ng'uuru Gakirwe to grow exotic herbs organically, and to manage the handling and processing to international standards for export markets. Unfortunately, NGOs are project based and with a defined time-span, and sometimes they fold, leaving farmers vulnerable to the shocks of changing production and marketing trends of new products. This happened at Mitunguu Irrigation Scheme, before farmers switched to growing bananas.

\section{Private sector involvement}

In the studied irrigation schemes, the private sector provided training services in situations where the smallholder irrigators were out-growers of major exporters, as at Mukuria-Kyambogo and New Mutaro irrigation schemes. In 
order to meet the EUREP-GAP export standards, the exporting company sends its own staff to identify competent farmers, then through regular visits and some group-based training the farmer is given practical training in crop husbandry, pest and disease management, water and environment, hygiene and sanitation, crop handling, packaging, record keeping and all the details required to meet EU standards. Usually, such farmers become highly specialized in the produce they grow. With the advent of mobile phones, the interaction between the company staff and farmers is well synchronized to address specific problems, and therefore meet timely market demands. At the time of this study, these types of extension services were offered "free" by the parent company. Capacity development is as important as capital investments and infrastructure. Penning de Vries et al. (2004) observed that governments, investment banks and donors can promote private sector participation in agricultural water use for poverty reduction, food security and economic growth through capacity development.

\section{Farmer-to-farmer exchange visits and learning}

All seven irrigation schemes involved some aspects of farmer-to-farmer learning. In some cases it was supported by NGOs. In other cases, farmers learned from each other through visits and at group meetings organized by government extension workers. At Emening, for instance, the self-help group organized its own meetings and farmers visited each other as they came from a background of pastoralism. At Ng'uuru Gakirwe, farmers who were not certified as organic growers would visit those who were certified and learn to grow their own organic herbs, to the extent that the scheme had a long list of farmers waiting to be certified. Farmer-to-farmer learning has been identified as a major tool for accelerating the diffusion and adoption of innovative technologies especially among smallholder land users in eastern Africa (Critchley et al., 1999; Mati, 2005; Kibwana, 2001). The region has seen many years of trials with farmer participatory learning such as on-farm research, farming systems, training and visits, rapid and participatory rural appraisals, farmer participatory methods and farmer field schools which have been tested with rain-fed agriculture (Norman et al., 1994; Chambers et al., 1989; Haile et al., 2001; Duveskog, 2001). However, the same has not happened under irrigated agriculture, and therefore farmer-to-farmer learning is not as well organized. New reforms for the irrigation subsector are needed to address capacity development strategies tailor made for smallholder irrigated agriculture.

\section{CONCLUSIONS}

This paper has profiled the role of capacity development in seven irrigation schemes in Kenya, namely: Emening, Lari-Wendani, Mukuria-Kyambogo, New Mutaro, Isiolo RWUA, Mitunguu and Ng'uuru-Gakirwe, considered sustainable and successful in reducing poverty. An important observation was that the initial investment costs for smallholder irrigation schemes range from about US \$198 to \$1744 ha ${ }^{-1}$, while net earnings range from US \$200 to $\$ 1200$ per month for major crop enterprises. However, even with these successes, farmers engaged in irrigated agriculture are still faced with diverse problems such as (i) marketing, price instability and the problem of middlemen, (ii) how to sustain management of group activities and (iii) water shortages, especially with demand for expansion to outlaying areas. This study has demonstrated that, regardless of how poor the farmers were to begin with, poverty and food insecurity at community level were reduced within two to three years through well-organized irrigation.

The importance of capacity development for smallholder irrigators is an important input. It was noted that most of the farmers come from a background of rain-fed agriculture or agro-pastoralism and irrigation in these areas was a relatively a new venture. Farmers therefore require training by trainers who are well grounded in the unique crop husbandry of exotic crops and irrigation technologies. It was noted that NGOs and the private sector were more effective in providing capacity development for the more exotic crops and market-oriented production. However, farmer-to-farmer learning, through exchange visits and field days, brought in more practical aspects and led to faster replication of innovations. In general, there is no targeted training of extension workers specifically for irrigated agriculture in Kenya, and this requires action by the relevant sectors. With the Irrigation and Drainage Department having been moved from the Ministry of Agriculture to the Ministry of Water and Irrigation, there is a 
need for the Department to consider either recruiting their own extension staff or retraining those from Agriculture to be more relevant to the dynamic and regularly changing irrigated crop production. In the future, communities and the private sector will play a leading role in enhancing learning for irrigated agriculture. Strategies to facilitate their success need to be laid out and implemented.

\section{REFERENCES}

Baiya FM. 2000. Focal Area Extension Planning: Field Guide Notes. National Agricultural and Livestock Extension Programme, Ministry of Agriculture and Rural Development, Nairobi, Kenya.

Chambers R, Pacey A, Thrupp LA (eds), 1989. Farmer First: Farmer Innovation and Agricultural Research. Intermediate Technology: London; Collaborative Program Partners: IWMI, Pretoria.

Critchley W, Cooke R, Jallow T, Njoroge J, Nyagah V, Saint-Firmin E. 1999. Promoting farmer innovation: harnessing local environmental knowledge in East Africa. Workshop Report No. 2, UNDP Office to Combat Desertification and Drought and RELMA, Nairobi, Kenya.

Duveskog D. 2001. Water Harvesting and Soil Moisture Retention: A Study Guide for Farmer Field Schools. Ministry of Agriculture and Farmesa: Sida, Nairobi, Kenya.

Gautam M. 2000. Agricultural Extension: The Kenya Experience, An impact evaluation. World Bank: Washington, DC.

Haile M, Abay F, Waters-Bayer A. 2001. Joining forces to discover and celebrate local innovation in land husbandry in Tigray, Ethiopia. In Farmer Innovation in Africa: A Source of Inspiration for Agricultural Development, Reij C, Waters-Bayer A (eds.). Earthscan: London; $58-73$.

Herdijk A, Diemer G, Kimani J, Mukolwe M, Thairu M(eds). 1990. Evaluation of Small-Scale Irrigation Development Projects: Smallholder Irrigation: A Large Challenge. Ministry of Agriculture, Irrigation and Drainage Branch: Nairobi, Kenya; Ministry of Development Cooperation: Netherlands.

Irrigation and Drainage Department (IDD). 2003. Summary of Strategic Plan, 2003-2008. Ministry of Water Resources Management and Development: Nairobi, Kenya.

Irrigation and Drainage Department (IDD). 2006. Irrigation sector in Kenya: status and challenges. Paper presented at Green Water Credits Workshop, 11-12 October 2006, KARI, Nairobi, Kenya.

Kenya Agricultural Research Institute (KARI). 2001. Working with partners to respond to farmers technology and information demands. ATIRI Manual, Agricultural Technology and Information Response Initiative (ATIRI), Nairobi, Kenya.

Kibwana OT. 2001. Forging partnerships between farmers, extension and research in Tanzania. In Farmer Innovation in Africa: A Source of Inspiration for Agricultural Development, Reij C, Waters-Bayer A (eds) Earthscan: London; 51-57.

Mati BM. 2002. Use of geographic information systems for planning and management of small-holder irrigation and drainage. In The Changing Face of Irrigation in Kenya: Opportunities for Anticipating Change in Eastern and Southern Africa, Blank HG, Mutero CM, Murray-Rust H (eds) International Water Management Institute (IWMI): Nairobi; 75-91.

Mati BM. 2005. Overview of water and soil nutrient management under smallholder rain-fed agriculture in East Africa. Working Paper 105, International Water Management Institute (IWMI), Colombo, Sri Lanka http://www.lk.iwmi.org/pubs/working/WOR105.pdf [accessed in 2006]

Mati BM, Penning de Vries FWT. 2005. Bright spots on technology-driven change in smallholder irrigation. case studies from Kenya. In: Bright Spots Demonstrate Community Successes in African Agriculture. Working Paper 102: 27-47, International Water Management Institute http://www.iwmi.cgiar.org/Publications/Working_Papers/working/WOR102.pdf [accessed in 2006]

Ministry of Agriculture and Rural Development (MoA\&RD). 2000. National Agricultural and Livestock Extension Programme. Project document, Nairobi, Kenya.

Ministry of Water Resources Management and Development (MoWRM\&D). 2003. Framework for formation and management of water users associations: towards sustainable community-based smallholder irrigation and drainage development. Nairobi.

National Agricultural and Livestock Extension Program (NALEP). 2004. The National Agricultural and Livestock Extension Program, Phase Ii, July 2005-June 2010. NALEP II Report No. 1, Ministry of Agriculture and Ministry of Livestock and Fisheries Development, Nairobi, Kenya.

Norman DW, Siebert JD, Modiakogotla E, Worman FD. 1994. Farming systems research approach: a primer for eastern and southern Africa. FS Program, UNDP, Gaborone, Botswana.

Okoth JR, Khisa C, Thomas J. 2002. Towards a holistic Farmer Field School approach for East Africa. Leisa Magazine 8(3): 11-19.

Penning de Vries F, Inocencio A, Sally H, Nakhumwa C. 2004. Opportunities for private sector participation in agricultural water development and management. Review of literature report submitted to the African Development Bank.

Pickering D. 1989. Agricultural extension and its linkage with agricultural research. In Agricultural Extension in Africa: A World Bank Symposium, Roberts N (ed) World Bank: Washington, DC; 3-6.

Republic of Kenya. 2003. Summary of Strategic Plan (2003-2008). Irrigation and Drainage Department, Ministry of Water Resources Management and Development, Nairobi, Kenya.

Republic of Kenya. 2004. Strategy for revitalizing agriculture 2004-2014. Ministry of Agriculture and Ministry of Livestock and Fisheries Development, Nairobi, Kenya.

Republic of Kenya. 2006. Economic Survey 2006. Central Bureau of Statistics, Ministry of Finance and Planning. Nairobi, Kenya. 